ter, supervise and coordinate all operation of modern 200000 volume three-story well-designed facility serving 3,400 students $(2,800$ FTE $)$. $\$ 18,500$ minimum, faculty status, excellent fringe benefits plus moving allowance. Appointment date no later than August I, 1976. Apply with vitae and references by March 8 to Office of Provost. Attn: Library Director Search Committee, Pacific Lutheran University, Tacoma, WA 98447 . An equal opportunity/ affirmative action employer.

Respondents to advertisers offering laculty "rank" and "status" are advised that these terms are ambiguous and should inquire as to benefits involved.

All advertisements submitted by institutions offering positions must include a salary range. The range should provide the applicant with an indication of the salary the institution is willing to provide for the position offered.

All advertisements for the Positions Wanted and the Positions Open classifications will be edited to exclude direct or indirect references to race, creed, color, age, and sex as conditions of employment.

Classified advertising orders and copy, and cancellations, should be addressed to the Advertising Department, 50 East Huron Street, Chicago 6061I, and should reach that office before the second of the month preceding publication of issue desired. Copy received after that time may be held for the next issue.

Telephone orders for classified advertising, while not encouraged because of the increased risk of copy error, will be accepted. Calls should be directed to Leona Swiech at (312) 944-6780. A confirming order should be mailed to the Advertising Department as soon as possible following the call, along with typewritten copy to be used in proofreading the ad.

Rate for classified advertising is $\$ 1.30$ per printed line.

\title{
POSITIONS WANTED
}

LIBRARIAN, MINISTER, CHRISTIAN EDUCATOR seeks position in a small college, using some or all fields of competency. Have BA, MRE (in '55) MS (in '64) plus seminary (no Hebr.) Ordained '55, experience all fields - served as College Head Librarian. Seminary Assistant Librarian (Cat.), rural pastorates, missionary to Choctaw Indians; also managed several large estates as executor, conservator. Available Spring 16, R. L. Mabson, 3754 Highland Park, Memphis, TN 3811 I.

MLS SEEKS ENTRY LEVEL POSITION. BA Anthro minor Asian Studies, 4 yrs. teaching Am. Civ. in Francefluent in French. 5 yrs. paraprofessional library workref. \& circulation: public \& univ. Interests: bibliography \& book selection. Prefer West or Atlantic Coasts. Available Sept. 76. Write C\&RL NEWS Box 85I, 50 E. Huron St., Chicago, Illinois 60611 .

ASSISTANT PROFESSOR in Allied Health Sciences desires position in special or academic library. MLS from accredited school, CMA, BA. Strong language back ground. G. Heckman, 8 Club Drive, E. Pitisburgh, PA 15236.

\section{POSITIONS OPEN}

ASSOCIATE LIBRARY DIRECTOR. Tulane University, Executive officer in charge of day-to-day operation of library, personnel, physical plant. On occasion Acting Library Director. Graduate degree in library science; experience in academic library administration; ability to deal effectively with staff, faculty, students: strong interest in research library problems and opportunities. 12month appointment: $\$ 17,0 \mathrm{CO}-\$ 20,000$; TIAA.CREF; month's vacation. Resumes before May to: Library Director, Tulane University Library, New Orleans, LA 70118. An equal op portunity/affirmative action employer.

COLLEGE LIBRARIAN. Carleton College seeks a qualified person to direct the College Library with appointment effective July I, 1976. The salary will be not less than $\$ 16,000$, but will depend upon qualifications and expe rience. Send nominations and resumes to: Prolessor $J . C$ Perry, Acting Director of the Library, Carleton College Northfield, MN 55057. An equal opportunity/affirmative action employer.

\section{Cataloging}

INSTRUCTOR, GENERAL PURPOSE CATALOGER. Three year contract. Renewal possible depending on perform ance and instifutional finances. Available February I 1976, closing date March I, 1976. Original cataloging o monographs in English and Western European languages in all disciplines. Qualifications: MLS from an ALA ac. credited library school. One year original caraloging in an academic library using LC classifications and subject headings. Reading knowledge of French required. Combi nation of French and one other Western European language desirable. Salary and benefits: $\$ 10,906$ for a 12 month contract. Hospital/medical benefits paid in part by employee. Apply to: H. William Axtord, University Librarian, University of Oregon, Eugene, OR 97403. An equal opportunity/affirmative action employer.

University of California, Davis is now accepting applications for the position of Principal CATALOGER/AS SISTANT HEAD of the Catalog Department. RESPONSIBILITIES: Training and supervision of professional and para-professional stafl numbering 15 FTE pasitions. This assignment entails continuing review on a sample rather than a full-time revision basis. The ability to plan. organize, and supervise cataloging operations is essentia as is the ability to write with clarity and precision. The Principal Cataloger/Assistant Head works closely with the Department Head in the planning and coordination of department procedures and is in charge of the de partment during the Head's absence. The appointee will be expected to spend 2 to 4 hours per week answering questions at the Catalog Information Desk. This will include occasional weekend work OUALIFICATIONS: A graduate degree in librarianship from an $A L A$-accredited institution; a minimum of 3 years' cataloging experience in an academic library using LC Classification. Salary: Hiring range is $\$ 14,256-\$ 16,872$, dependent on qualifications and experience, with rank of Associate Librarian. The salary range for this position runs to $\$ 20,868$. Send resumes to: Wm. F. McCoy. Associate University Li brarian, 108 Shields Library, University of California Davis, CA 95616.

Multiple

ASSISTANT SCIENCE LIBRARIAN (LIBRARIAN II). Selection for life science collection: coordinates library instruction and information; reference. Minimum qualifications: MLS; undergraduate degree in biology, chemistry or medical technology: 3 years' professional experience, strong outreach commitment essential $\$ 11000+$ VISUAL COLLECTIONS LIBRARIAN (LIBRARIAN II). Administers visual collections facility for slides, photos, plans, films,

LIBRARY DIRECTOR: Director of University Library. Doc torate preferred minimum MLS plus additional postbaccalaureate degree; at least IO years' professiona library experience, primarily administrative, to adminis. 
in Architecture 19 th and 20th $C$ art urban design, en vironmental art; reference, acquisitions and special proi ects. Minimum qualifications: MLS; graduate degree or extensive background beyond undergraduate degree in architecture, art hist.; 3 years' experience in architecture, art or visual collections: German Italian or French, ad ministrative and supervisory skills, $\$ 11,000+$. Resumes to: Suanne Muehlner. Assistant Director for Personnel Services, The Libraries, 14S-216 MIT, Cambridge, MA 02139. An equal opportunity employer.

1. REFERENCE LIBRARIAN. Three years' reference experience in academic library required. Additional pro fessional experience in other areas desirable. 2. MAP LIBRARIAN. Two or more years' experience in map li. brarianship and general reference required with undergraduate degree in geography-geology. Graduate work in cartography highly desirable. Supervisory experience necessary. 3. EDUCATIONAL RESOURCES LIBRARIAN. Media specialist with three to five years' experience in media service to users required. Doctorate or education specialist degree with major course work in educational systems technology, instructional media, or audio-visual education is desirable and two master's degrees in one of these fields or a combination thereof, including library science, would be beneficial. 4. ORDER LIBRARIAN. Three or more years' experience in order work plus other technical service activities and bibliography required with knowledge of the book trade in general and its specialized sources. Supervisory and teaching ability necessary. 5. CATALOG LIBRARIAN. Three to five years' experience in cataloging required with expertise in calaloging and classification theory, rules and procedures. Subject specialty must be in arts and humanities cataloging. Work experience with OCLC terminals highly desirable. Knowledge of Western European and other languages preferred. 6. CONTINUATIONS CATALOG LIBRARIAN. Three years of cataloging experience with particular emphasis on serials required. Knowledge and interpretation of serials records necessary. Some knowl. edge of automation approaches to serials desirable. 7. CONTINUATIONS CATALOG LIBRARIAN. Three vears of cataloging experience required with ability to organize and interpret microform cataloging records. Work entails cataloging variety of microforms ranging from news papers to books and periodicals. Service to users may be required. All candidates must possess MLS accredited degrees except as specified in No. 3. Academic ranks based upon the educational background and years of experience. Salary depends upon rank, e.g. instructor $\$ 7,833-\$ 14,101$, assistant professor $\$ 10,173-\$ 16,739$ eic Send resume and official transcripts before February 29 1976 to Dr. Ray R. Suput, Department of Library Service. Ball State University, Muncie, IN 47306. Equal oppor. tunity/affirmative action employer.

\section{Public Services}

ASSISTANT, CIRCULATION/MEDIA. To assist the heads of adiacent departments in administration of general and reserve circulation, collection maintenance, use and control of media collection, and management of Self-instructional Media Center. Qualifications: MLS from an accredited library school. Experience prelerred but not mandatory. Salary: $\$ 13,000+$ depending on qualifications. Governors State University is a new upper-division state university with a growing enrollment (approaching 5,000). located 30 miles south of Chicago. Send resumes by March 15, 1976 to: Ms. Barbara Smith Chairperson, Search Committee, Learning Resources Center, Governors State University, Park Forest South, Illinois 60466. Affirmative action/equal opportunity employer.

READERS SERVICES HEAD. San Francisco State University. Minimum 4 yrs, exp. incl. ref. \& mgmt. resp. Will supervise approx. II prai., 9.5 staff. Req: MLS \& Subi. MA or Equiv. Sal. \$18,156. Send resume \& transc. to: Readers Serv. Search Comm., S.F. State Univ. Lib., 1630 Holloway Avenue, S.F., CA 94132. An affirmative action employer.

\section{Reference}

HEAD CENTRAL REFERENCE LIBRARIAN: The University of Arizona is seeking a professional librarian to ad- minister the Central Reference Department. This department will be created when the Main Library is moved to a new building in the fall of 1976 and will include general reference material as well as special tools in the subject areas of the social sciences and humanities. The Head Central Reference Librarian will coordinate the development of the collection, supervise a staff of approximately 9 professional librarians and 7 library assistants, oversee interlibrary loan operations, and actively promote the use of the library. Several years of professional service, including administrative experience in a reference department, is required. Applicants for this position must be graduate of an ALA-accredited library school. Preference will be given to candidates with a broad academic background in the social sciences or humanities and an ability to read and speak Spanish. Librarians at the University of Arizona have 12-month appointments with 22 days per year of paid vacation. and a standard package of academic holidays and other fringe benefits. The minimum salary will be $\$ 14000$ Ap. plications will not be accepted after March 15, 1976. Send resumes and inquiries to: Mary Dale Palsson. Assistant Librarian for Public Services, University of Arizona Library, Tucson, AZ 85721. An equal opportunity/affirmative action employer. Minorities and women are encouraged to apply.

REFERENCE. Two positions as Assistant Librarian $1 \$ 10$ $716-\$ 15,084)$ or Senior Assistant Librarian $(\$ 12,600-\$ 17$ 292). Both levels require second master's degree or progress toward same; Senior Assistant requires two years' experience. Background in physical science, business, or computerized data bases highly desirable. Department is a unified service with seven librarians. One evening each week and four or five weekends each semester. Request application form from Henry Madden University Librarians. California State University Fresno $\mathrm{CA} 93740$. An equal opportunity/alfirmative action em ployer.

SOCIAL AND BEHAVIORAL SCIENCES REFERENCE LIBRARIAN. Position open September 3, 1976 due to tirement. Reference, orientation, and callection development responsibilities. Accredited MLS and undergraduate major in psychology, sociology, political science, graphy, or anthropology in that order of preference. Salary as Instructor $\$ 10,108-\$ 13,540$ for 9 months; possi bility of summer employment. Appointment at highe rank and salary possible. Send letter of intent and resume by March I. 1976 to Martha Donahue, Chairperson. Recruitment Committee, Mansfield State College Library, Mansfield, PA 16933. An equal opportunity employer.

Subject Specialists

DOCUMENTS LIBRARIAN. Michigan Technological University. Graduate degree in library science from a school accredited by the American Library Association. Extensive experience with government materials prelerred. Salary $\$ 9,100$. Faculty status, retirement pension. paid hospitalization insurance, 24 days vacation, 13 days sick leave. Apply to Michael V. Krenitsky, Library Director. Michigan Technological University, Houghton, MI 49931. An equal opportunity/affirmative action employer.

CURATOR OF GERMANIC LANGUAGES COLLECTIONS (Librarian |I-III) Salary: $\$ 13,000-\$ 18,500$. Responsible fo evaluation and development of collections in Germanic languages required for research and teaching objectives of Stanford University. Selects current and retrospective materials, corresponds with vendors and publishers, executes selection policies of Stanford University $\mathrm{Li}$ braries, maintains close relationships with faculty in ap propriate academic departments. Requires literate, articulate individual of demonstrated scholarly and bibliophilic competence, sound knowledge of German language literature, culture, history, and bibliography, personal qualifications which will permit collaboration with faculty as a colleague. Advanced training in philology, linguistics, history, and philosophy, and experience in research libraries or the book trade highly desirable. Send resume to Paul Mosher, Asst. Director lor Collection Develop. ment, Stanford University Libraries, Stanford, CA 94305. An equal opportunity/affirmative action employer.

BIBLIOGRAPHER. The Institute Library has a unique col. lection of traditional and contact material and is the 
major clearinghouse for information on all matters relating to Australian Aborigines. The Institute requires a Bibliographer to work particularly on an expanded bibliography of culture contact. Applicants should ideally have an MLS and a degree in one of the Social Sciences, and at least two years of cataloging/bibliography/reference experience. Knowledge in computer analysis would be an asset. The salary range is $\$ A 11,229-11,610-11,991$, according to experience and qualifications. Economy airfares and reasonable removal expenses are offered. Applications with three academic references should be forwarded as soon as possible to the Executive Officer Australian Institute of Aboriginal Studies, PO Box 553, CANBERRA CITY, ACT 2601 Australia.

LIBRARIANS for Social Science Library. Assignments include relerence/government documents cataloging. Appointments begin September I, 1976. MLS, Social Science background required. Second degree or advanced academic praining in psychology, business administration. or law desirable. Cataloging experience with AACR re quired for one position only. Salary $\$ 11,000$ up depending upon qualifications. Faculty status. Send resume and three letters of reference to Dr. G. Donald Smith, Director of Libraries. Washington Stafe University, Pullman, WA 99163, by April 30, 1976. An equal opportunity/ affirmative action employer.

SCIENCE REFERENCE LIBRARIANS, Reference responsibilities, selection of materials, liaison with faculty and

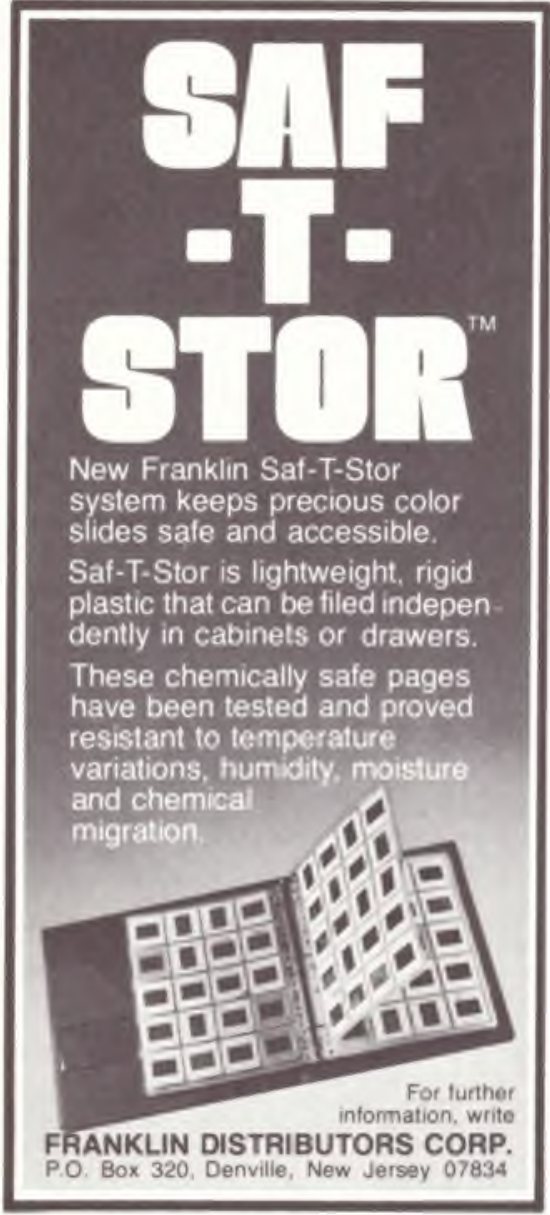

students in designated subject area, class instruction, leadership responsibility in a technical activity. Qualifications: MLS; 2 yrs. experience, science library preferred science subject background desirable. Faculty status, TIAA, Salary: \$11,500 up. Open July 1. 1976. Send resume to Dr. G. Donald Smith, Director of Libraries, Washington State University, Puliman, WA 99163 before May I, 1976. An equal opportunity/aflirmative action employer.

SOCIAL SCIENCE BIBLIOGRAPHER-Responsible for material selection and reference service in the Social Sciences. Requires MLS and Master's or Doctorate in Sociology, Psychology. Anthropology, Economics, Political Science, Geography, or Business. Experience required except in the case of MLS-Ph.D. combination. Salary $\$ 10$. $500-\$ 13,500$ depending on gualifications. Must relate well to faculty, students, and library staff. Position available July 1, 1976. Send resume to: G. Jay Rausch, Dean of Libraries, Kansas State Unıversity, Manhattan, KS 66506. An equal opportunity/affirmative action employer.

LIBRARY INSTRUCTION LIBRARIAN. Responsible for the development and administration of one-hour library instruction course required of all incoming freshmen and sophomores. Course to be taught using auto-tutorial method. Qualifications: MLS from accredited library school, two to three years of experience in college-level relerence work necessary. Administrative experience and familiarity with auto-tutorial education very desirable. Twelve-month contract, salary commensurate with experience and qualifications, minimum $\$ 11,500$. Position available June, 1976. Write Dr. Michael F. Kelly, Director of Libraries. The University of Texas at San Antonio, San Antonio. TX 78285. An equal opportunity emplover.

\section{Technical Services}

SYSTEMS AND PLANNING LIBRARIAN-To review, up date, and integrate library routines and procedures, both manual and automated: develop long range plans and recommend procedural, organizational methods which will increase the effectiveness of the library. Also to develop, on a short term basis, the detailed plan for moving the general library into a new building in late 1976. Minimum qualifications include a master's degree from an accredited library school; three years' experience in an academic library; thorough knowledge of man agement techniques, including the application of elec tronic data processing to library operations, A second master's degree (or equivalent) is desirable. Minimum salary: $\$ 14,000$ for a twelve month contract. Fringe bene lits include Illinois Retirement System benefits, academic status, and one month vacation. Applicants should send their resume and personal relerences to $\mathrm{Mr}$. George $M$. Nenonen. Personnel Director University Libraries. Northern Illinois University, DeKalb, IL 60115, before March I, 1976. An equal opportunity/affirmative action employer.

ASSISTANT DEAN FOR TECHNICAL SERVICES, University of New Mexico. ESSENTIALS are: 6 years of ad ministrative experience in a university or research li brary: direct supervisory experience in cataloging, acquisitions or serials; experience in automated systems (preferably in the uses of OCLC): demonstrated organizational abilities with strong leadership qualities: MLS with a second master's or doctor's degree; active participation in state, regional and national library associations. HIGHLY DESIRABLE: good publication record managerial experience in a large technical service division; teaching experience. The present technical staf includes 13 full time professionals, 4 para-professionals and a total library budget of $\$ 2.7$ million. REMUNERATION5: Minimum salary $\$ 20,000$. Full faculty status including tenure and sabbaticals, with faculty rank to be negotiafed with the Dean of Library Services. Position is available immedialely. Send resumes and three references by March I, 1976 to chairman. Search Committee for Assislant Dean of Technical Services. G. Martin Ruoss, Zimmerman Library, University of New Mexico. Albu querque, New Mexico 87131. Phone 505-277-5961. The University is an equal opportunity/affirmative action employer, actively seeking minority candidates. 


\section{For extra convenience in using Groice ...}

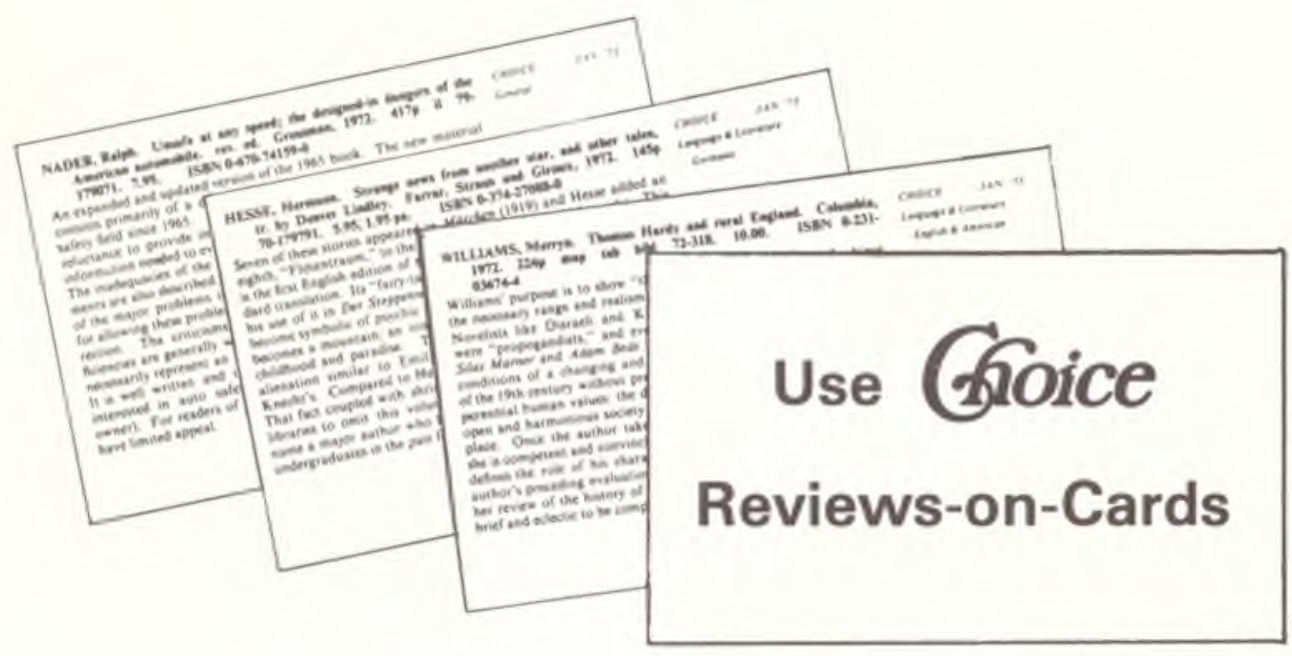

With the first issue of Volume 5 (March 1968), CHOICE began an additional service long requested by subscribers - CHOICE Reviews-on-Cards. If you were not among the service's charter subscribers, you may want to consider it now.

Reviews-on-Cards can make your acquisitions system as versatile as you like. They make it easy to separate and distribute reviews simultaneously to other librarians and faculty (no more tearing up magazines or waiting forever for circulating copies to return). They save clerical steps in ordering and checking holdings (ample space for notations on both sides). They are a cataloging aid, and they are easy to locate in your desiderata file. You will find dozens of uses for them.

As CHOICE goes to press, all reviews are reprinted on $3 \times 5$ cards. Each is identified by subject and issue date. Collated in the order followed in the magazine, they are boxed and mailed to you via Fourth Class mail, Special Handling. You should receive them within three weeks after your regular issue of CHOICE.

A year's subscription to Reviews-on-Cards (available only to CHOICE magazine subscribers) costs $\$ 110.00$. With current publication of approximately 6,500 reviews per year, the cost of the card service is only $1.7 \llbracket$ per review. 


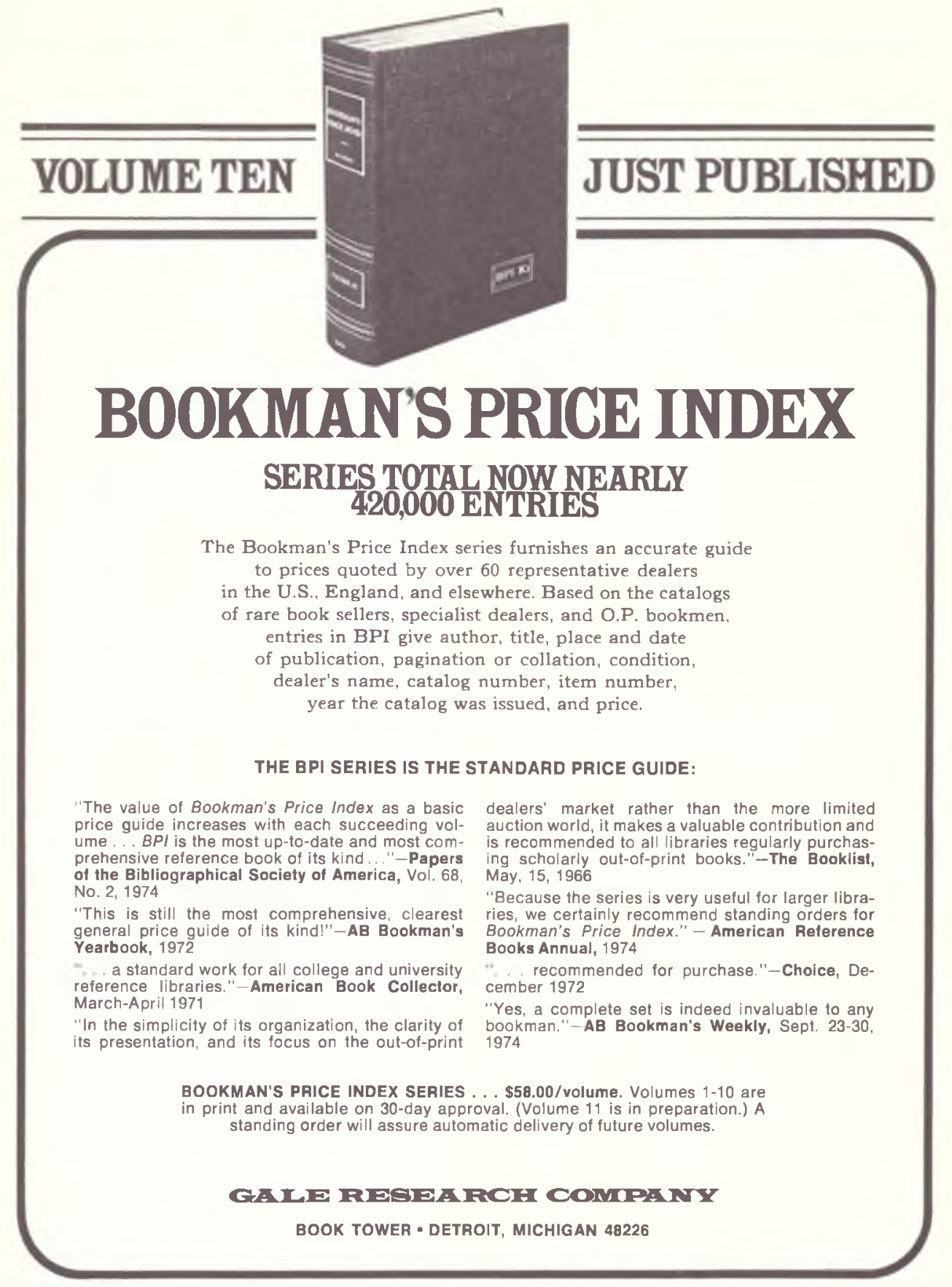

